\title{
Theory and Evidence on the Relationship between Leadership Style and Organizational Performance: A Case in Small Medium Enterprises in East Malaysia
}

\author{
Dato` Dr. Jelani Bin Hamdan ${ }^{1}$ \\ ${ }^{1}$ Põle Paris Alternance, IPE Management School Paris, France \\ Correspondence: Dato’ Dr. Jelani Bin Hamdan, Põle Paris Alternance, IPE Management School Paris, France.
}

Received: June 8, 2020

Accepted: June 29, 2020

Online Published: June 30, 2020

doi:10.5539/ibr.v13n7p265

URL: https://doi.org/10.5539/ibr.v13n7p265

\begin{abstract}
This research intends to provide the theoretical evidence on the relationship between leadership style and organizational performance of small medium enterprises (SMEs) in East Malaysia. The growth organizational performances among SMEs in East Malaysia have been at stagnant stage, as they are not able to respond to unforeseen issues due to weak leadership. The SMEs in East Malaysia are losing their competitive advantages as compared to West Malaysia. There is lack of motivation among the followers working in SMEs in East Malaysia as employees do not put extra effort in their tasks. There is absence of creativity in workplace as employees have not been giving any productive output from a long time. Previous research have documented that there are relationships between leadership style and organizational performance in SMEs in East Malaysia. The current study steps forward to contribute to gaps in body of knowledge by looking at the effects that occur due to different leadership style and its influence on the organizational performance in SMEs in East Malaysia. The nature of this study add to the existing literature by integrating the theory and evidence that could enhance organizational performance.
\end{abstract}

Keywords: leadership style, organizational performance, Small Medium Enterprises (SME), East Malaysia

\section{Introduction}

Organizational performance is the performance of any organization can be judged by examining their final outcomes after the implementation of certain plan or procedure. It has seemed that end results prefer by organizations and their relevance to measuring whether the business increasing or decreasing in terms of productivity and efficiency. Also, these results used to identify the further progress of a company in short-term and long-term (Cameron \& Whetten, 2013). The previous survey has illustrated that more than 50\% organizations rely on their performance measure for the formation and execution of further strategies. They believe that current performance has a huge influence over the future development of business ( $\mathrm{Li} \&$ Tan, 2013). In the annual review, 30\% organizations have presented that the growing issues in the economic system have caused destruction in their level of organizational performance. This situation will continue in the future if organizations fail to improvise their existing work system (Buoziute-Rafanaviciene, et al., 2015). The balanced scorecard is utilized by more than $50 \%$ organizations for the measurement of elements related to organizational performance (Valmohammadi \& Ahmadi, 2015). The contribution for employment by small medium enterprises in East Malaysia was 66 percent and GDP is 37\% in 2017, which is below average hence an indication of problems in organizational performance, and the poor organizational performance can be attributed to lack of entrepreneurial skills, funding, knowledge, and skills in management as well as marketing under new the economy (Neil, 2019).

The State Finance Ministry in 2019 State Budget allocated some funds for local entrepreneurs to further develop their business with statistics indicating there are over 43,000 people involved in small medium enterprises who lack of adequate funds to enhance their earnings as well as provide employment opportunities for the locals, hence an indication of problems in organizational performance through job creation and profit maximization (Daily Express, 2019a). According to Royce (2019), out of 50,000 small medium enterprises in Malaysia, only 300 have signed up for the evaluation for the selection process for a complimentary readiness assessment (RA) on readiness for fourth industrial revolution and this is an indication of poor preparedness as an outcome of 
problems in leadership style as well as organizational performance as they lack a matrix and framework to focus on.

Sabah Tour and Travel Association (Satta) Chairman Datuk Seri William Liaw pointed out that Sabah is underperforming in providing entertainment for tourist which is an indication of serious problems in the organizational performance of small medium enterprises in East Malaysia (Sherell, 2019). With over 600,000 Chinese arrivals in 2018, Sabah is ranked behind Thailand, Indonesia, and the Philippines in tourism service provision. According to Glassdoor rating statistics, review rating score of a Sabah SME X-FAB Sarawak is 3.5 out of 5.0, with numerous people on the complaining about X-FAB Sarawak, which is an indication of problems organizational performance, for instance, an Engineer in Kuching, Sarawak pointed out that he walks to car park at least 10 minutes and gets sunburns because no roof, in addition, has to spend RM 5 every day for cafeteria food which can be provided for free by management (X-FAB Sarawak, 2019). Subsequently, based on leadership performance, reviews indicate serious issues in leadership in Sarawak Energy Berhad with a rating score of 3.2, such issues include career progression is based on race and seniority, supervisors and managers do not bother to get people who registered to handover their knowledge and tasks, office politics which affects increment and performance appraisal, slow promotions and lack of career growth (Sarawak Energy Berhad, 2019). Another problem in SMEs in East Malaysia like SEGi University has scored a rating of 2.4 out of 5.0 and $26 \%$ approve of CEO, from the reviews, as there is a very slow career and salary growth, increasing workload, fussy bosses who cheat to get work done, the management do not know actually what they are promising and non-flexible management, hence most of the staffs are unhappy and less satisfied (SEGi University, 2019).

Also, there are numerous negative reviews on SOPB such as traditional organization framework and monthly salary below market rate, discouragement of innovation hence limited growth, since the employees just deal with fixed and mundane tasks on daily basis, employees are rarely given the chance to grow and even have to work on Saturdays (SOPB, 2019). The local terrain and market of Sabah and Sarawak is around six million people, however, there have been challenges to exploit this large customer base due to lack of correct strategy, hence an indication of a problem in leadership style by small medium enterprises in East Malaysia which can facilitate implementation of new strategies to collaborate with other foreign firms to exploit this opportunity (Madani, 2019). A serious problem faced by SMEs in East Malaysia is poor planning, the negative reviews from employees in SMEs in East Malaysia are quoting that management does not have a clear direction to guide the employees through, as well as planning only happens when issues have already occurred (X-FAB Sarawak, 2019). Moreover, the lack of corporation from key personnel and top management on various matters is another indication of problems in SMEs in East Malaysia, for instance there are numerous negative comments on Rimbunan Sawit Berhad, which are including lack of corporation by top management on safety \& health matters and most people speak their own dialect (on Rimbunan Sawit Berhad, 2019).

The growth organizational performances among SMEs in East Malaysia have been at stagnant stage, as they are not able to respond to unforeseen issues due to weak leadership (Lee \& Lam, 2012). The SMEs in East Malaysia are losing their competitive advantages as compared to West Malaysia (Mustafa Kamal \& Flanagan, 2012). There is lack of motivation among the followers working in SMEs in East Malaysia as employees do not put extra effort in their tasks. (Bakar \& Mahmood, 2014). There is absence of creativity in workplace as employees have not been giving any productive output from a long time (Moghimi \& Subramaniam, 2013). The middle line managers making decisions among SMEs in East Malaysia are not effective as they are not able to meet the specific team goals (Arham, et al., 2013). The speed of work is at slow process as the actual time of completing tasks exceeds from expected deadlines (Ping, 2015). There seems to be high dependency on the leader among SMEs in East Malaysia as employees are not able to cope-up with uncertain situations on their own (Al-Swidi, et al., 2012). There is lack of new ways for conducting jobs as managers ask employees to complete work as per traditional ways (Masa'deh, et al., 2016). There is low level of enthusiasm among employees working in SMEs in East Malaysia as workplace seems boring (Yagambaram, 2012). There is high level of rules, regulations and punishments given to employees, which increased turnover rate (Asiimwe \& Sikalieh, 2012). Employees are leaving the company every month. Hence, the main purpose of this research is to explore on the theoretical evidence on the relationship between leadership style and organizational performance of SMEs in East Malaysia.

\section{Literature Review}

\subsection{Theories}

\subsubsection{Great Man Theory}

Great Man Theory (year 1840) analyzes effects of leadership style on organizational performance of SMEs in East Malaysia. The founder of this theory is Thomas Carlyle and found in year 1840 (Faludi, 2013). The 
evolution of Great Man Theory from 1840s has been done after the study of influential heroes. In the initial stages, it was not easy to identify who the great leaders are. The theory was recognized by its name only, that only men are the leaders. It showed that leadership traits are intrinsic. As per the theory, leaders are born not made (Marx, 2014). Further research is needed on Great Man Theory because the scope of leadership training has changed. The training sessions and seminars regarding the importance and usage of leadership qualities are conducted in order to make them effective. The shift in mentality has also been experienced, that is why further research is to be conducted (Yusuf \& Kazeem, 2014). The extended theoretical framework on Great Man Theory should be based on leadership qualities particularly. Leaders are not always by birth leaders, they are also trained time to time. Many of them learn from their experiences. The attributes of great man theory must be according to the analysis of situation (Hamerstone \& Hough, 2013). Great Man Theory suggest to solve the research problems on organizational performance by the application of different leadership styles. These five leadership styles can add to enhance the performance of the organization. The first researcher Marx (2014) who proposed Figure 2.1 own model to study the list of rare factors affecting the Great Man Theory includes the traits which are focused upon the intuition, charm, commanding personality and the persuasiveness that exists. The second researcher Hamerstone and Hough (2013) who proposed Figure 2.2 own model to study the list of rare factors affecting the Great Man Theory established that the personal charisma tops the priority for rare traits within leaders. The similarity in their proposed models between the first researcher Marx (2014) and the second researcher Hamerstone and Hough (2013) is that these studies work on how important the personality trait of charisma is for successful leadership. Researchers understand the importance of using charisma and charm in a way that they are able to achieve the objectives that are set. The difference in their proposed models between the first researcher Marx (2014) and the second researcher Hamerstone and Hough (2013) is that Marx (2014) shows that leadership is a combination of the four traits. On the other hand, Hamerstone and Hough (2013) believe that the personal charisma is more important for a leader. The reason is that it helps power through different challenges.

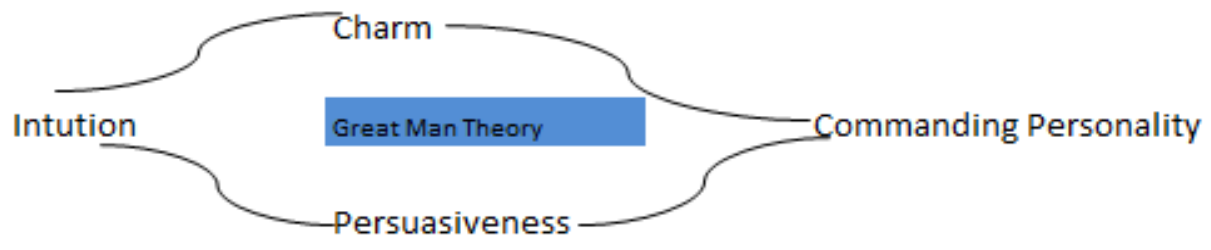

Figure 2.1. Great Man Theory by Marx (2014)

(Source: Marx, 2014)

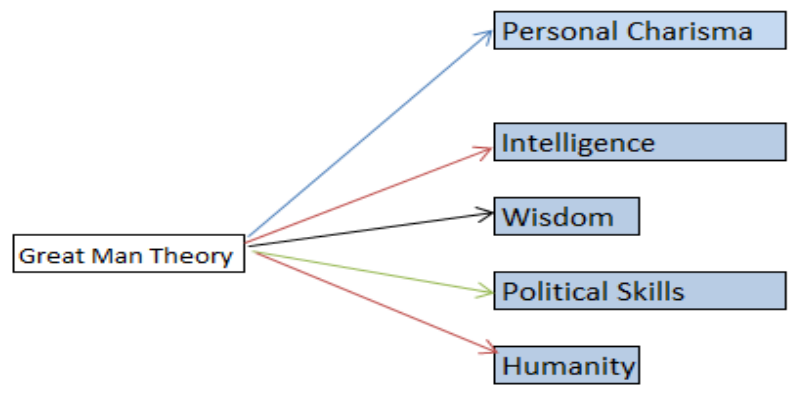

Figure 2.2. Great Man Theory by Hamerstone and Hough (2013)

(Source: Hamerstone and Hough, 2013).

\subsubsection{Trait Theory}

Trait Theory (year 1974) analyzes effects of leadership style on organizational performance of SMEs in East Malaysia. The founder of this theory is Raymond Cattell and found in year 1974 (Ryckman, 2012). Evolution of Trait Theory from 1940's gets an emphasis in the beginning of 1970's. The theory initially included only the big five traits of personality. Emotional intelligence gained favour by 1980's as a crucial trait. The theory is known to be an effective tool for sustaining the organizational performance. The reason is that employee's trait affect the 
overall performance (Paraschiv, 2013). Further research is needed on Trait Theory because the past research does not focus on the changes in the leadership trait over a period of time. The traits vary according to the situation, hence further studies are to be carried to discuss this factor. Further research is needed because the theory does not emphasise on personality changes during different situations (Clack, 2017). Figure 2.3 extended theoretical framework on Trait Theory should be on the basis of changing of behaviour and traits by the time. It emphasised over the need of flexibility within the leader and their ability to use the energy during uncertain situations (Silva, 2015). Trait Theory suggested to solve the research problems on organizational performance by examining the changing in traits form person to person. The theory can be effectively used when the traits are being applied based on the situations. The first researcher Manning (2014) who proposed Figure 2.4 own model to study the list of rare factors affecting Trait Theory, which are, the intelligence, initiative, and supervising ability linked with self-assurance and decisiveness. The second researcher Northouse (2015) who proposed Figure 2.5 own model to study the list of rare factors affecting Trait Theory, which are, the clear link that exists amongst the leadership trait and patterns and the consistency of the patterns across different situations. The similarity in their proposed models between the first researcher Manning (2014) and the second researcher Northouse (2015) is that the leadership skills are often in-built within individuals. If they use these traits successfully, the leadership objectives are attained. Moreover, researchers agreed that the individuals have certain leadership emergence skills which differentiate them and lead to the mutual success. The difference in their proposed models between the first researcher Manning (2014) and the second researcher Northouse (2015) is that the second researcher had more emphasis over helping develop a link that used the leadership traits of an individual to establish patterns of behaviour. It is not an aspect that is covered by the first researcher whose main focus has been to differentiating the abilities, personal traits and motivators.

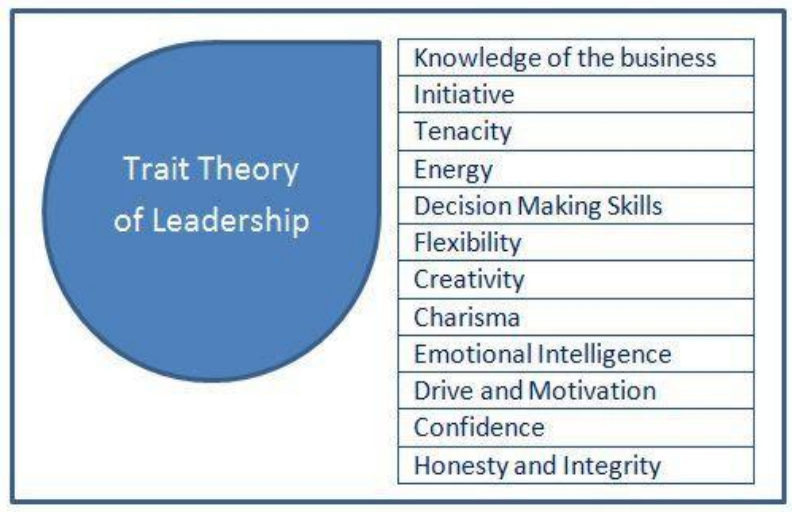

Figure 2.3. Extended Framework of Trait Theory

(Source: Manning, 2014)

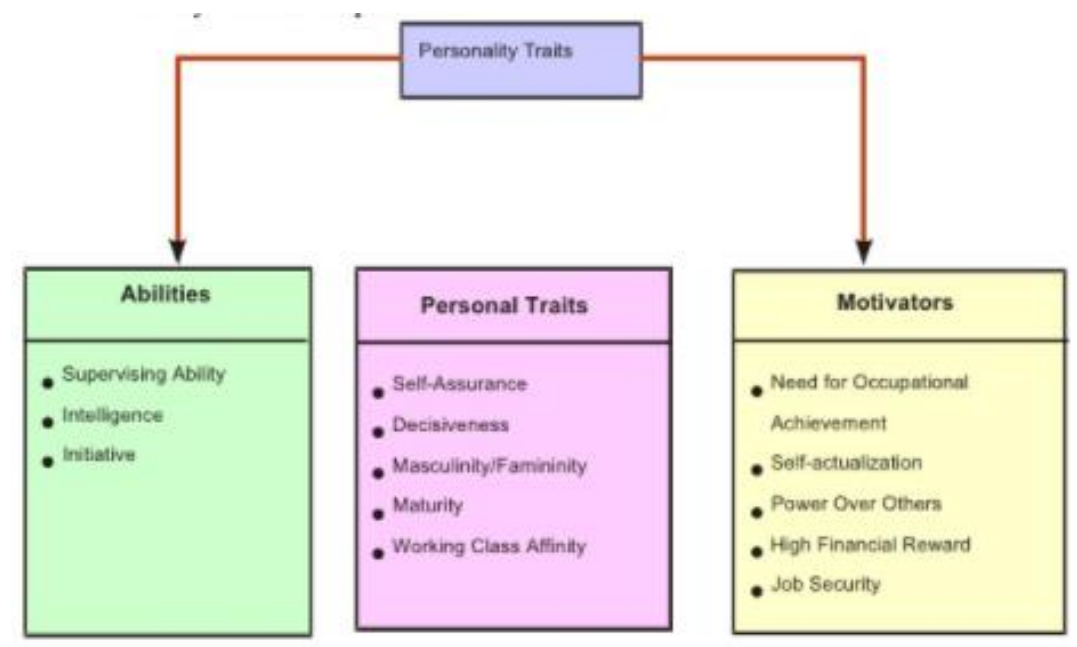

Figure 2.4. Trait Theory by Manning (2014)

(Source: Manning, 2014) 


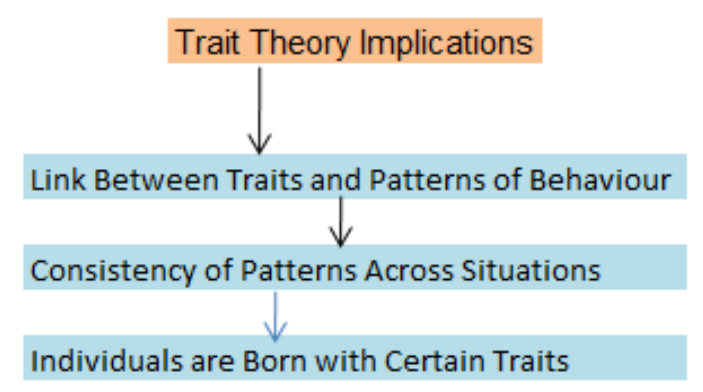

(Source: Northouse, 2015)

Figure 2.5. Trait Theory by Northouse (2015)

\subsubsection{Role Theory}

The Role Theory (year 1987) analyzed the effects of leadership style on organizational performance of SMEs in East Malaysia, because it deals with the role of individuals conducted on everyday basis such as norms, behaviours, duties and rights of managers (Koenig, \& Eagly, 2014). The founder of this theory is Alice Eagly and found in year 1987 (Franke, Crown, \& Spake, 1997). Evolution of Role Theory from social psychology helps in building the appropriate leaders for the organizational sustainability. The theory did not have to wait for social modelling in order to be applied. The application of role theory is related to the day to day situation as it can be simply produce (Clack, 2017). Further research is needed on Role Theory because it has restrained time, space and specific situation of real life. The role player might not be exactly playing its role on what is required in that proposed situation. For the correct interpretation of this theory, more studies are required to be done (Harnich \& Frank, 2012). Extended theoretical framework on Role Theory should also include the variables related to variations in role. The person who is assigned a particular role might not be interested in that which creates a negative impact on the mind of that individual. The proper identification of roles is required to be defined. Role Theory suggests to solve the research problems on organizational performance by interpreting the correct form of role that has to be assigned. It can make the relation and moulding of rights to get strong for the organizational benefit. The first researcher Harnich \& Frank (2015) who proposed Figure 2.7 own model to study the list of rare factors affecting Role Theory, which are the effect of social learning and behaviour on the leader. It also emphasises over the role adoption and role expectations. The second researcher Drysdale, et al (2016) who proposed Figure 2.8 own model to study the list of rare factors affecting Role Theory, which involves what the leader wants to do and what the leader gets to do. It assesses the job dissonance. The similarity in their proposed models between the first researcher Harnich \& Frank (2012) and second researcher Drysdale, et al (2016) is that they analyze the influence of expectations over the leaders which in turn influence their decisions and successful goals and objectives. Overall, the similarity is evident as both researchers evaluate the final success of the role and how their objectives are achieved which sometimes lead to conflictions or dissonance. The difference in their proposed models between the first researcher Harnich \& Frank (2012) and second researcher Drysdale, et al (2016) is that the second researcher is more focused on how leaders' role dynamics might create a gap from what the leader actually wants to perform. These leaders have to adhere to the signals regarding the value-added leadership.

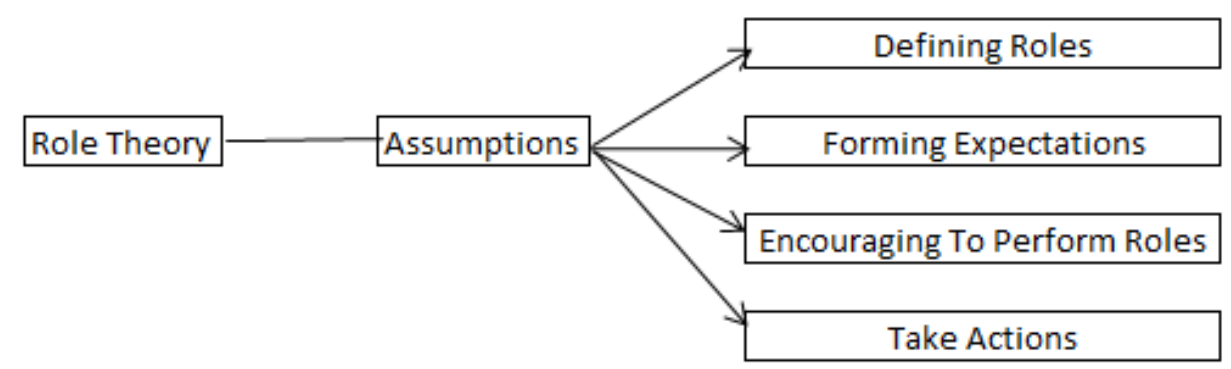

Figure 2.6. Extended Framework of Role Theory

(Source: Harnich \& Frank, 2012) 


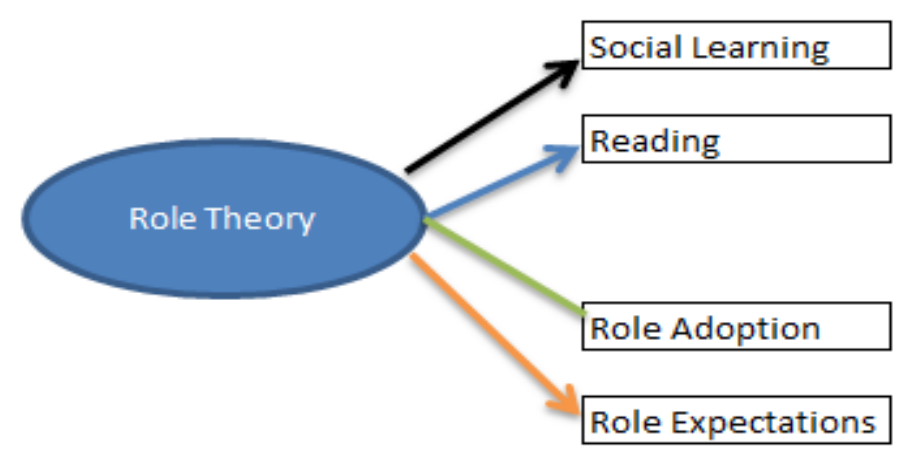

Figure 2.7. Role Theory by Harnich \& Frank (2015)

(Source: Harnich \& Frank, 2012)

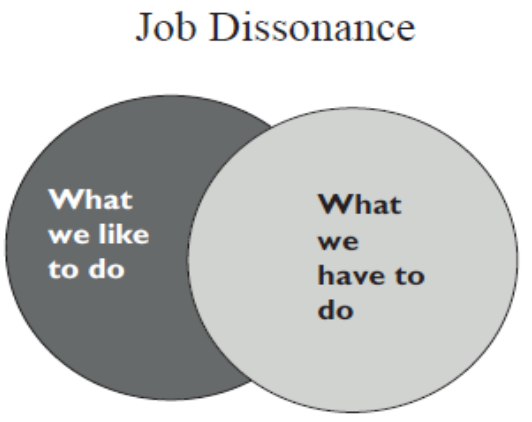

The Dissonance Factor

Figure 2.8. Role Theory by Drysdale, et al (2016)

(Source: Drysdale, et al, 2016)

\subsection{Organizational Performance}

The organizational performance is defined as the achievement of competitive advantage by the company for long-term. This performance can be measured in terms of tangible and intangible facets (Choudhary, Akhtar \& Zaheer, 2013). It is also defined as the comparison of the actual output of the company with its expected outcomes (Noruzy et al, 2013).

Financial parameters used to measure organizational performance are accounting measures such as stock price which evaluate value of a firm and accounting profits which establish the ability of a business to generate returns (Gundemir, et al., 2019). Definition of financial organizational performance is the efficiency of its assets, that is its employees to generate returns and is obtained from data collected from the past (Porkona and Castek, 2016). Another definition of financial organizational performance is the efficiency with which a firm manages its liquidity, solvency, and profitability for a given period of time (Fatihudin and Mochklas, 2018). Challenges to control financial organizational performance are changes in government regulation and increased competition from rival firms (Hanggraeni et al., 2019). Limitations to control financial organizational performance are the inability to upgrade technological assets accordingly and a poor marketing strategy which decreases sales (Srivastava, 2016).

Non-financial parameters used to measure organizational performance are the degree to which the clients of a firm satisfied and its innovativeness indicated by regular creativity in operations and products (Kotane \& Kuzmina-Merlino, 2017). Definition of non-financial organizational performance is that effectiveness of a firm that is expressed in the form of qualitative characteristics and includes client satisfaction and quality of products (Jorge and Borges, 2017). Another definition of non-financial organizational performance is the performance of a firm not in terms of its physical assets but intellectual capital (Kotane \& Kuzmina-Merlino, 2017). Challenges to control non-financial organizational performance are the inaccuracy of industry comparison as the methods used by some firms vary (Newark, 2018). Limitations to control non-financial organizational performance are the 
difficulty in calculating them as well as the long-period of time taken to arrive at an accurate performance value (Ashford, et al., 2018).

\subsection{Leadership Styles}

There are many types of leadership styles. Researcher has chosen particular leadership styles that are evident in SMEs in East Malaysia, they are charismatic leadership style, democratic leadership style, transformational leadership style, and transactional leadership style (Chan, 2010; Kele, et al., 2017; Ufen, 2015).

The theory that analyze development charismatic leadership style is Signalling Theory (Su \& Cheung, 2016). The founder of the Signalling Theory in the modern era are Connelly, Certo, and Reutzel and the year founded is 2011 (Connelly, et. al., 2011). The variables of the Signalling Theory include the indication of interest and excitement through an increased activity level. Furthermore, it showcases the vulnerability that exists from the competitors (Grabo, et. al, 2017). The factors that influence the variables of Signalling Theory are increased motivation level within the leaders and there is excessive use of creativity and strength (Nikoloski, 2015). The important role of Signalling Theory to influence the charismatic leadership style in affecting organizational performance is that it helps attract attention and arouse emotions (Nikoloski, 2015).

The theory that analyzes development of Democratic Leadership style is Critical Theory (Hudon \& Rouillard, 2015). The founder of Critical Theory is Max Horkheimer and the year found is 1937 (Horkheimer, 1937). The variables of critical theory are free will, emphasis on reason, pretentions of universality, presence of explanatory metanarrative, totalitarianism, consequences of massive industrialization and other options (Nagendra and Farooqui, 2016). The important role of Critical Theory to influence democratic leadership style in affecting organizational performance is that the theory emphasizes on enforcing new decisions in a way that there is increased participation amongst the employees (Yahaya, et. al, 2014).

The theory that analyze the development of Transformational Leadership style is Figure 2.9 Path-goal theory. The founder of Path-goal Theory is Robert House and year found is 1971 (House, 1974). The variables of Path-goal theory are participative goals, performance goals, satisfaction, vision, intellectual stimulation, expectations, rewards and the employee satisfaction (Vecchio, et. al, 2008). The factors that influence the variables of path-goal theory are the behaviour of the leaders that help create value (Henry, 2013). The important role of Path-goal Theory to influence transformational leadership style in affecting organizational performance is that it analyzes the goals of the followers. The objective is to enhance chances of success (Polston-Murdoch, 2013).

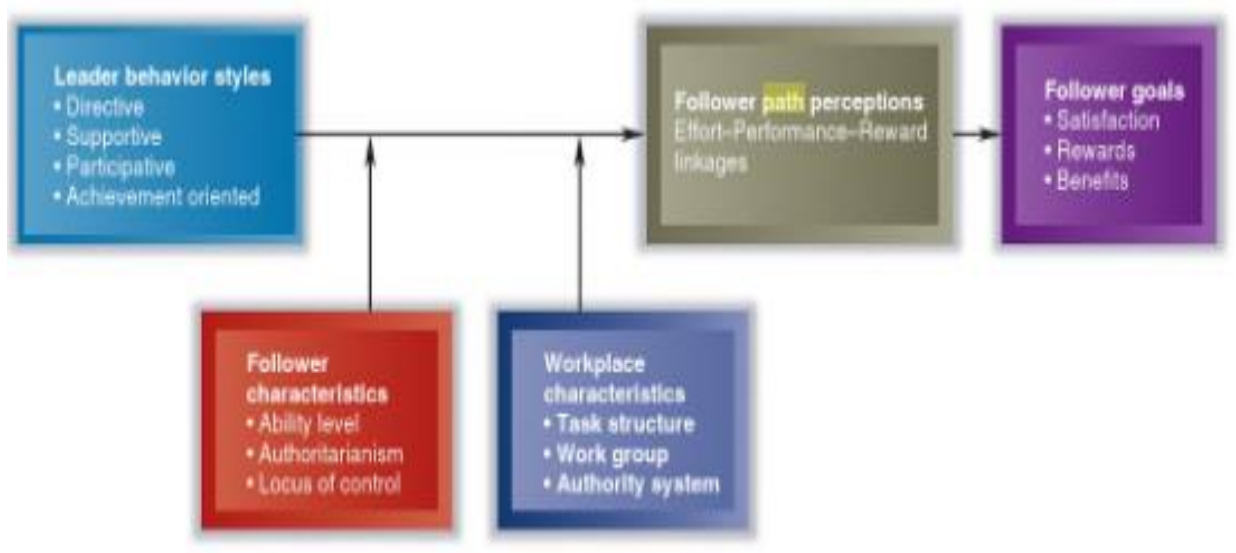

Figure 2.9. Theoretical Framework of Path-Goal Theory

(Source: Nelson \& Quick, 2013)

The theory that analyze development Transactional leadership style is Figure 2.10 Contingency Theory (Yishuang, 2016). The founder of Contingency Theory is John Woodward and the year founded is 1958 (Woodward, 1958). The variables of Contingency Theory are the importance of the situation in determining the effectiveness of leadership and the need for rewarding a good performance, a good leader has to evaluate the situation and act accordingly, equal importance to the assignments as well as the social or emotional challenges their team encountered, requirements of a situation must be well met by the leader's behavior, quintessential factor responsible for positive outcomes, motivation to be a crucial determinant of excellent leadership. The 
factors that influence the variables of Contingency Theory are follower compliance happens when overall motivation is captured (Linton, 2014).

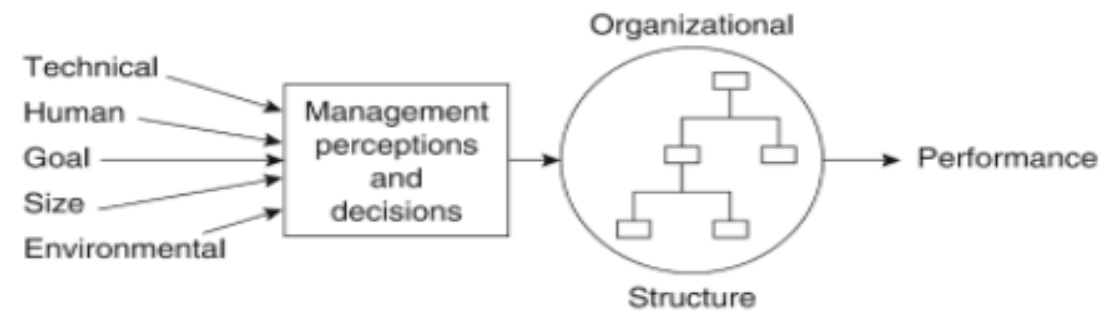

Figure 2.10. Theoretical Framework of Contingency Theory

(Source: Beckford, 2016)

\subsection{Evolution of Leadership Styles}

The evolution of the Signalling Theory occurred from covering the effect of the vision to ensuring that the energy is used effectively, it evolved in the late $20^{\text {th }}$ century (Khan, et. al, 2013). Further research is needed on the Signalling Theory because there is a lack of current studies on signals of charismatic leadership affecting organizational performance, the future research would augment the approach adapted (Kakucha, 2015). Figure 2.11 extended theoretical framework on Signalling Theory should be able to utilise the vision as the key to the theory. It would help formulate a long-term strategy. The extended theoretical framework can solve problems between charismatic leadership style and organizational performance analyzed in Para 1.0 as the variables emphasized on the use of the vision in a way that it aligns with the personality of the leader. The factors that influence variables of Signalling Theory are the highly motivational aspects which dictate the decisions made by the leaders when it comes to making successful coordination within the followers in times of emerging challenges. The first model that studied these factors is the Figure 2.12 evolutionary leadership model (Stutje, 2012). The variables of this first model analyzed that the most important aspect is the presence of charisma and vision. Figure 2.13 the second model that studied these factors that influence variables of Signalling Theory is the Three Levels of Leadership Model. The variables of this second model analyzed that there are outer levels and the inner levels that develop the leadership presence of an individual (Scouller, 2016).

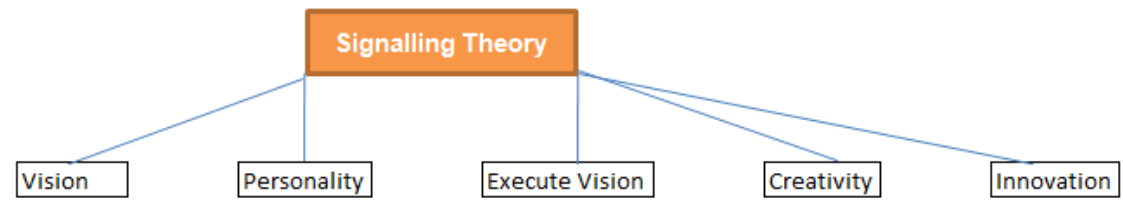

Figure 2.11. Extended Framework of Signalling Theory

(Source: Nagendra \& Farooqui, 2016)

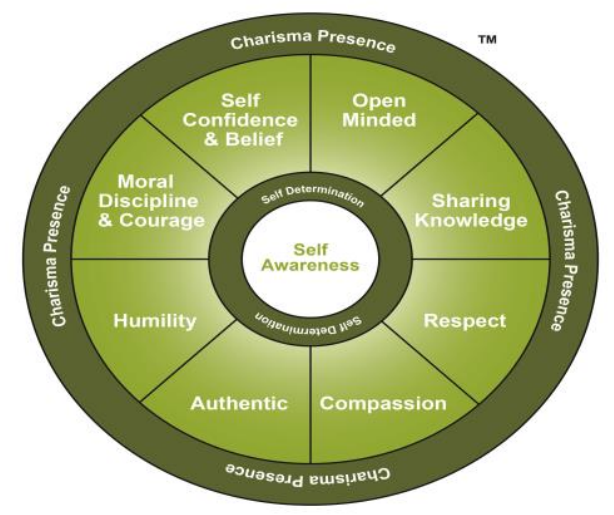

Figure 2.12. Evolutionary Leadership Model

(Source: Stutje, 2012) 


\section{The Three Levels of Leadership Model}

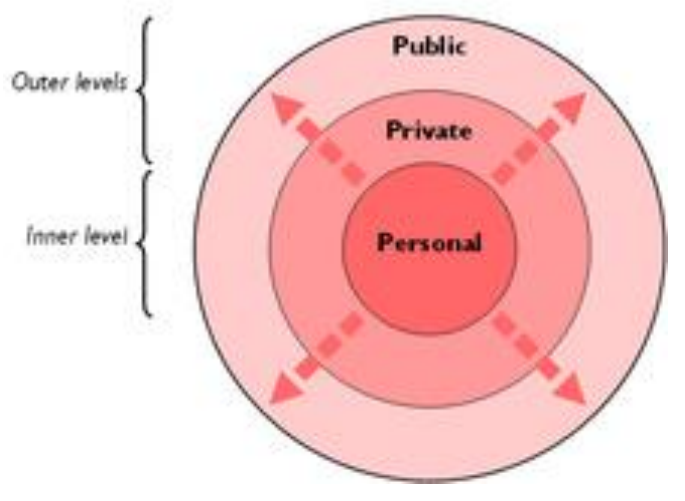

Figure 2.13. Three Levels of Leadership Model

(Source: Scouller, 2016)

The evolution of Critical Theory happened from the early $20^{\text {th }}$ century where the decision making had weak execution and strategies were analyzed to overcome the challenges, then the decision making is augmented (Akor, 2014). Future research is needed on Critical Theory because the managers do not have clear knowledge and understanding of the strategies they need to adapt. The new research can look into the motivational factors (Hudon \& Rouillard, 2015). Figure 2.14 the extended theoretical framework on Critical Theory should include social conditions, instrumental rationality and capitalism to evaluate democratic leadership in today's 21 st century. This extended theoretical framework can solve problem between the democratic leadership style and organizational performance analyzed in Para 1.0 as the variables emphasized on four key aspects, they covered the impact the social conditions, instrumental rationality, capitalism and totalitarianism have on the individuals. The factors that influence variables of Critical Theory are the emphasis that is put on the reasoning, without effective reasoning, most leaders are expected to face trouble in rationality and decision making (Akor, 2014). The first model that studied these factors is the Figure 2.15 Critical Leadership Decision Making Model. The variables of the first model analyzed are there has been an effect of the leadership reasons on the decisions, the leadership reasons tend to influence the leadership intention (Westaby \& Lee, 2010). Figure 2.16 the second model that studied these factors is Critical Elements of Reasoning Model. The variables of this model are the key factors that include the point of view from a reference, purpose of thinking goals or objective, information data, interpretation, concepts, assumptions, implications and consequences and lastly the information gathered altogether (Elder and Paul, 2010).

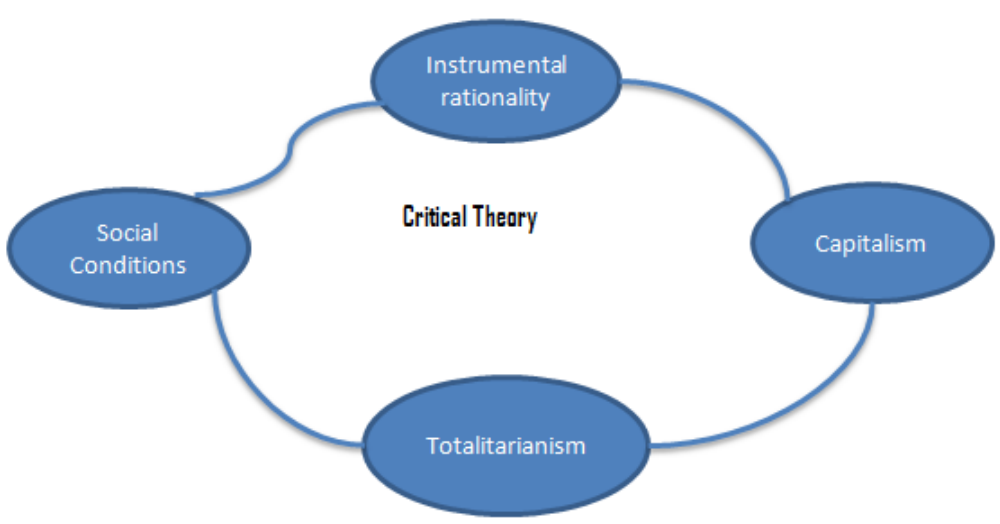

Figure 2.14. Extended Theoretical Framework of Critical Theory

(Source: Hudon \& Rouillard, 2015) 


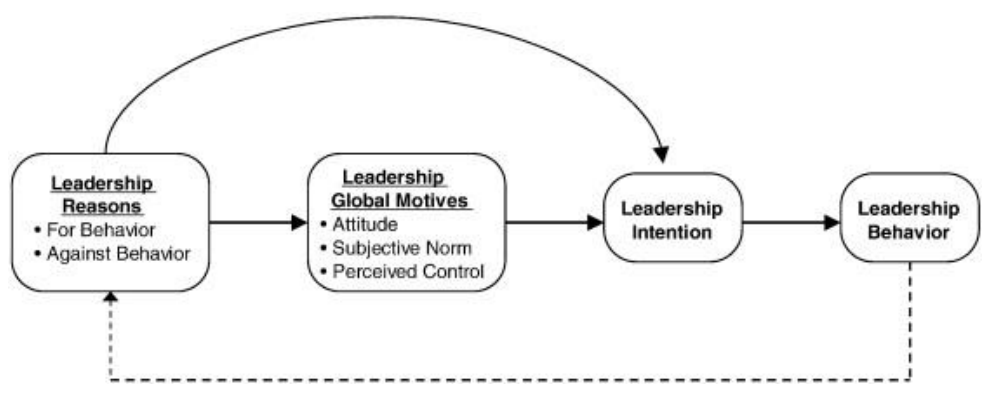

Figure 2.15. Critical Leadership Decision Making Model

(Source: Westaby \& Lee, 2010)

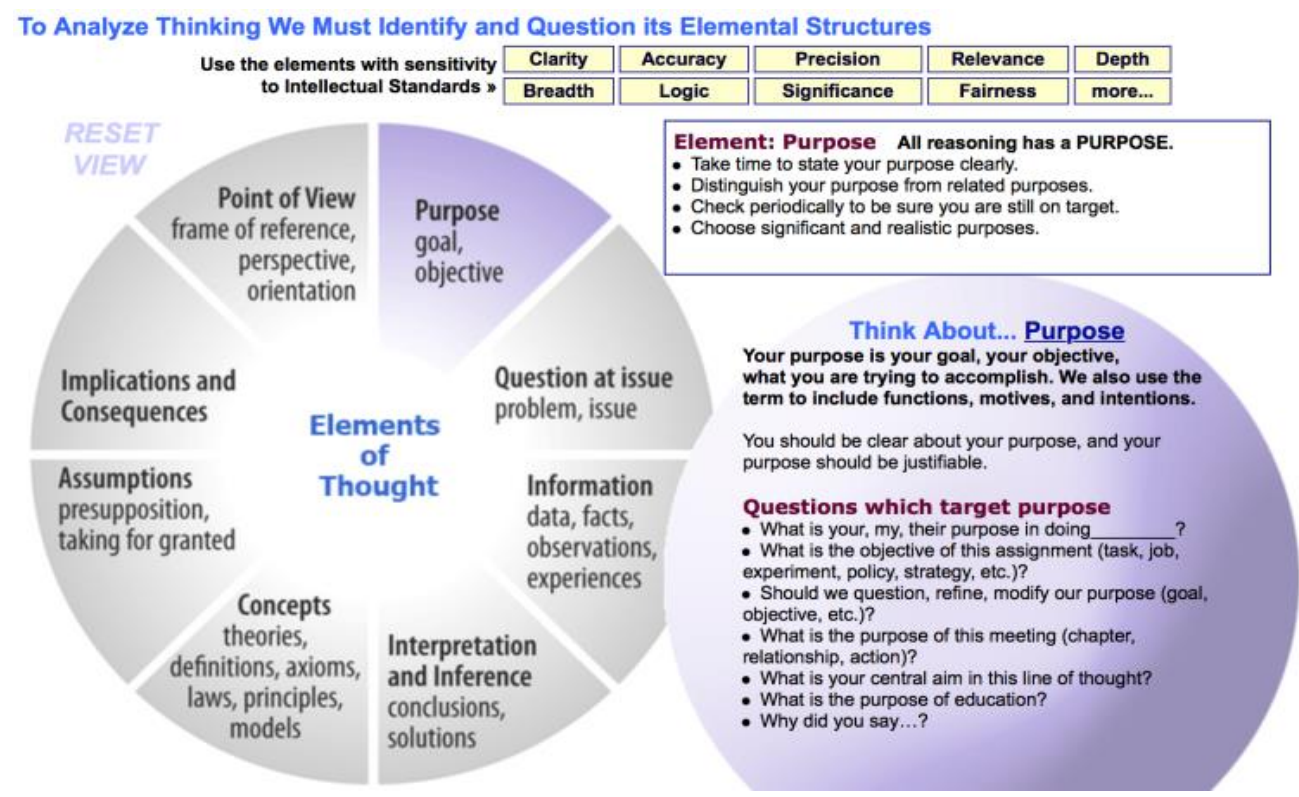

Figure 2.16. Critical Elements of Reasoning Model

(Source: Elder and Paul, 2010)

The evolution of Path-goal theory started from focusing on the work environment to implementing changes that would enhance the employees' motivation and empowerment successfully (Malik, 2013). The further research is needed on Path-goal theory because there is limited analysis on the economic impact on implementing path-goal theory in the business that is adapted by the leaders (Obiwuru, et al, 2014). Figure 2.17 the extended theoretical framework on Path-goal Theory should enforce the focus on situation which impacts the leader and followers (Northouse, 2016). This extended theoretical framework can solve problems between Transformational leadership style and organizational performance analyzed in Para 1.0 as the variables emphasized on ensuring that new strategies are followed. The factors that influence variables of Path-goal Theory are the specific style of leadership that meets the criteria needed to help achieve the tasks (Cavazotte, et al, 2013). The first model that studied these factors is the Figure 2.18 New Paradigm Model of Leadership. The variables of this first model analyzed that leadership phenomenon includes the belief that the leadership is a process and holds certain influence. The second model that studied these factors is the Figure 2.19 Leaders Multifactor Change Agents Model (Smither, et al, 2016). The variables of this second model analyzed the different change agents. The leader is at the middle of the model. 


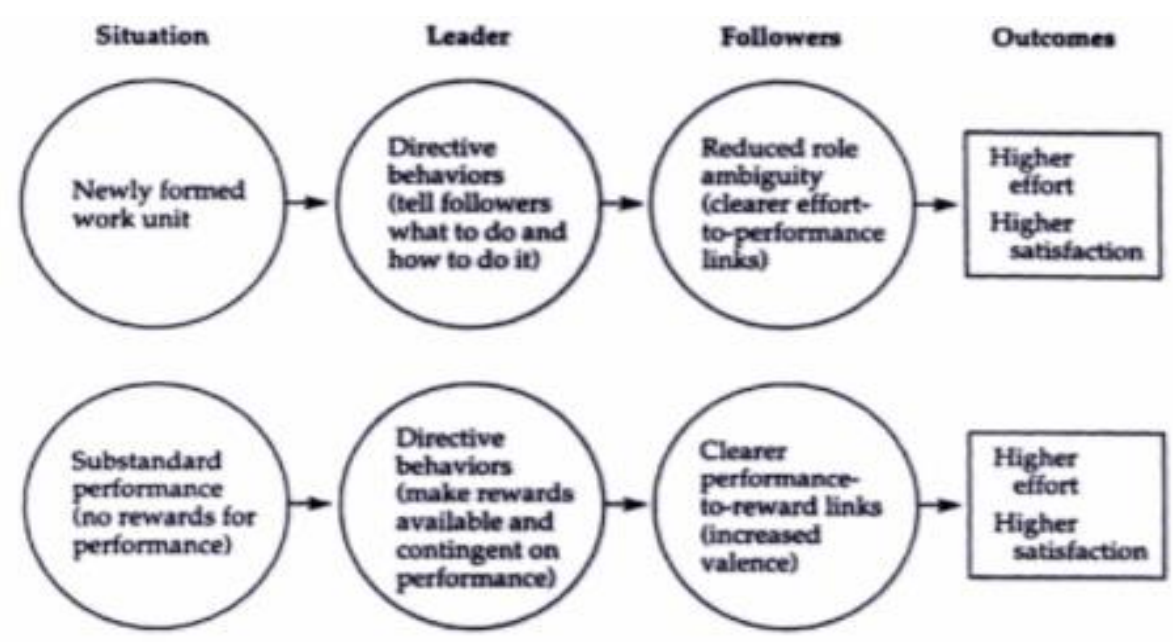

Figure 2.17. Extended Framework of Path-goal Theory

(Source: Northouse, 2016)

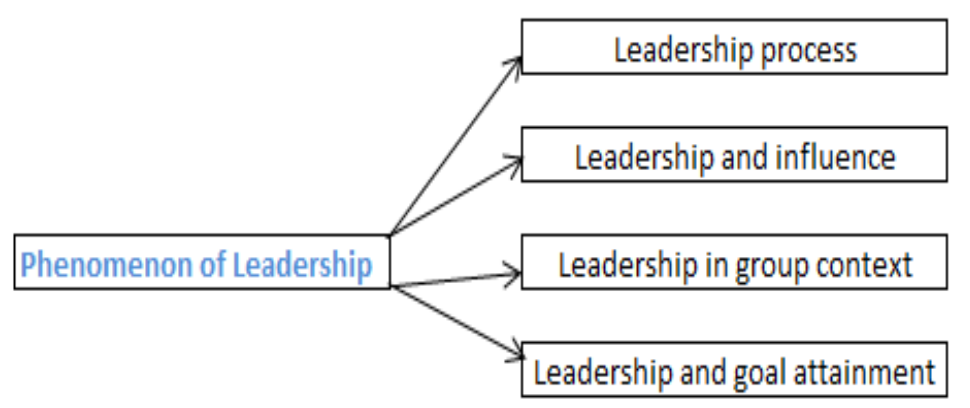

Figure 2.18. New Paradigm Model of Leadership

(Source: Magzan, 2012)

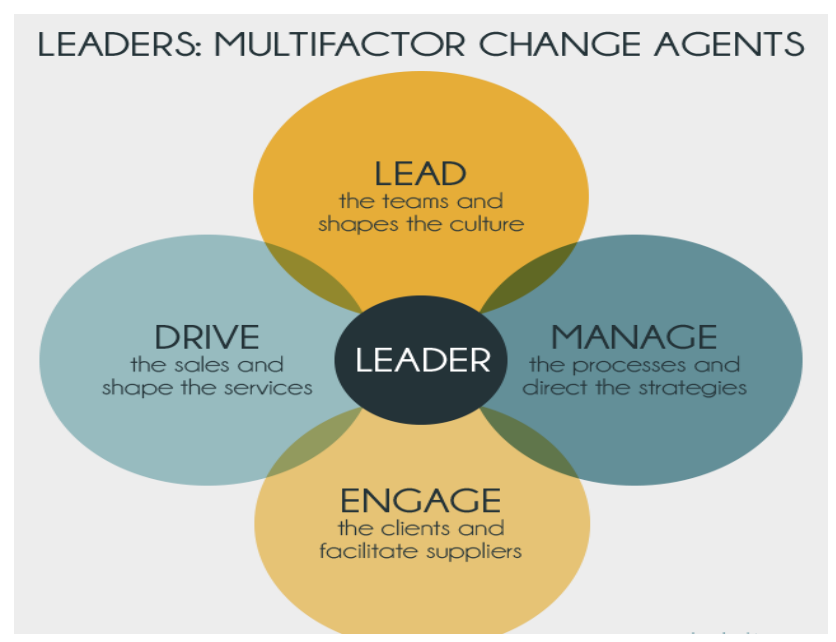

Figure 2.19. Leaders Multifactor Change Agents Model

(Source: Smither, et al, 2016)

The evolution of Contingency Theory has been such that it was first focused on the leadership and motivation. 
Gradually, it emphasised on determining the effectiveness of leadership and the need for rewarding a good pattern (McCleskey, 2014). The further research is needed on Contingency Theory because a clear representation of the benefits of transactional leadership style on organizational performance is not being researched in recent years, particularly in case of Malaysia SMEs. Moreover, its effectiveness in bringing organizational change is important (Sultana \& Darun, 2015). Figure 2.20 the extended theoretical framework on Contingency Theory should be able to help control the organization and ensure that the effectiveness is achieved to help cope with the social and emotional challenges. The extended theoretical framework can solve problems between Transactional leadership style and organizational performance analyzed in Para 1.0 as the variables emphasized on understanding the organizational objectives. The factors that influence the variables of Contingency Theory are the need to achieve the predetermined goals (Islam \& Hu, 2012). The first model that studied these factors that influence the variables of Contingency Theory is the Figure 2.21 Situational Leadership Model (Schermerhorn Jr, 2012). The variables of this first model analyzed that there are two different types of behaviour, the directive behaviour and the supportive behaviour. The second model that studied these factors is the Figure 2.22 Diamond model of Leadership (Beckford, 2016). The variables of the second model analyzed that there is an interconnection amongst the leader, task, organization and organizational structure. It also includes the followers with their attributes.

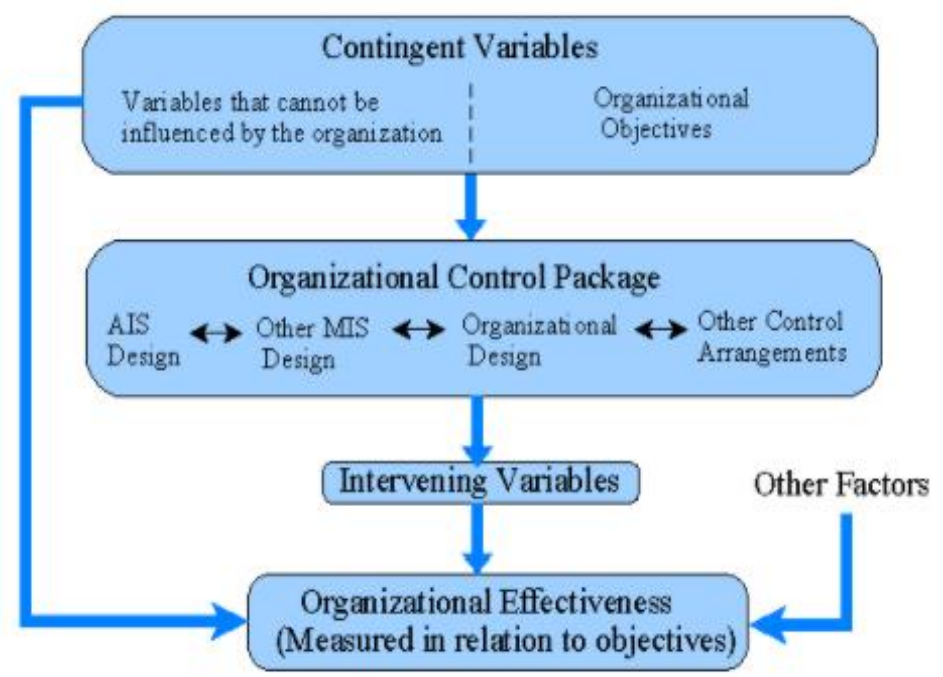

Figure 2.20. Extended Framework of Contingency Theory

(Source: Wickramasinghe \& Alawattage, 2012)

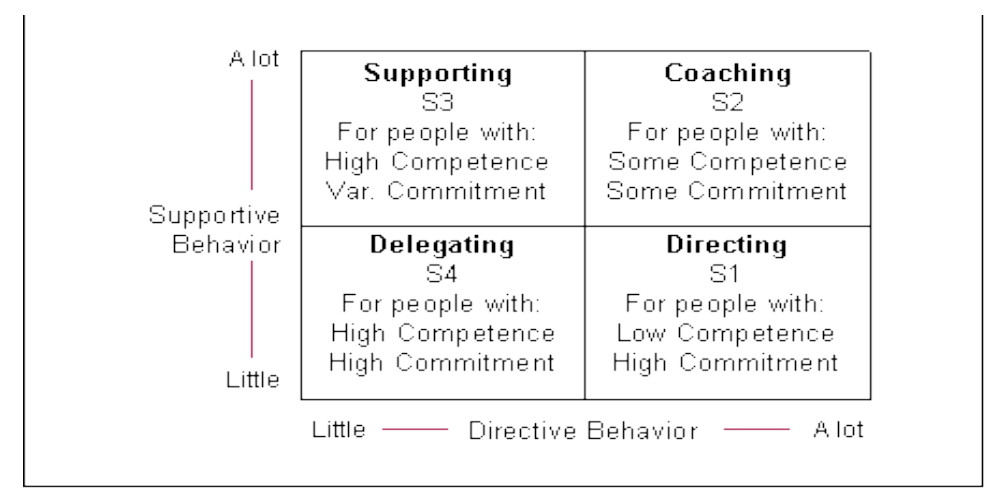

Figure 2.21. Situational Leadership Model

(Source: Schermerhorn, 2012) 


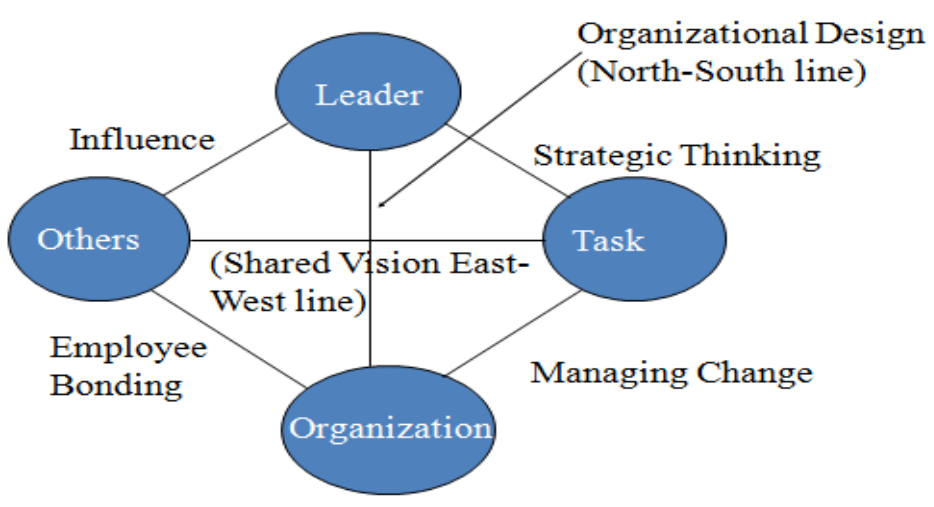

Figure 2.22. Diamond model of Leadership

(Source: Coleman \& MacNicol, 2016)

\subsection{Conceptual Framework}

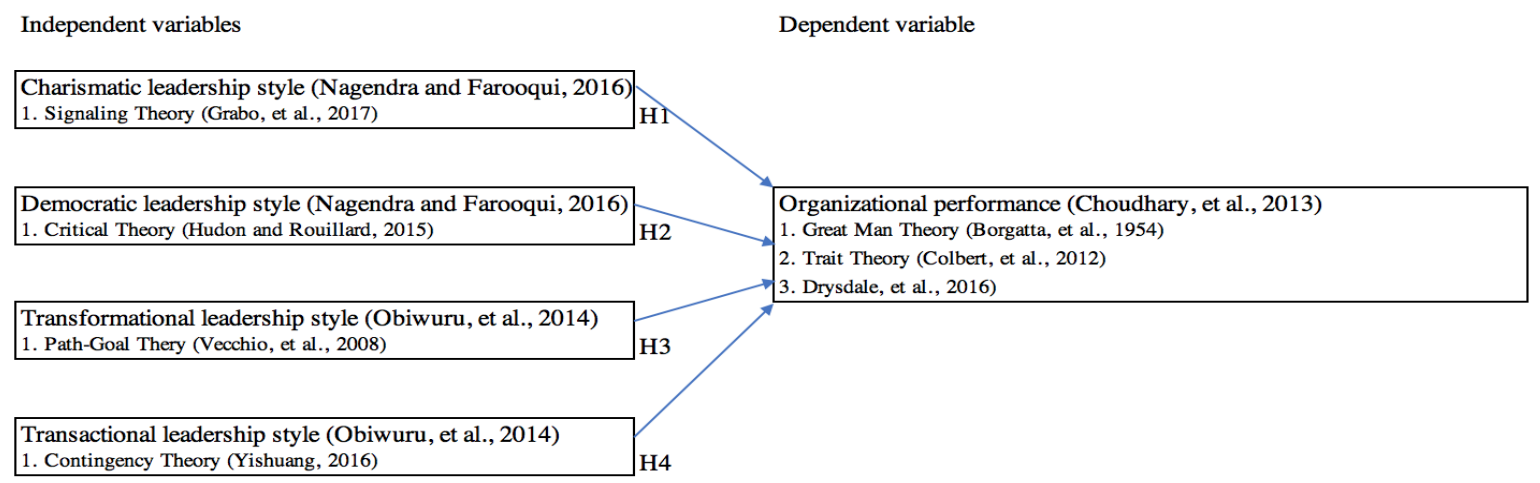

Figure 2.23. Theoretical Framework

Source: Adapted from: (Nagendra and Farooqui, 2016; Obiwuru, et al., 2014; Choudhary, et al., 2013; Grabo, et al., 2017; Hudon and Rouillard, 2015; Yishuang, 2016; Borgatta, et al., 1954; Colbert, et al., 2012; Drysdale, et al., 2016).

\section{Conclusion}

The first common trend among past literature reviews is substantial amount of energy is required for charismatic leaders to influence employees as attractive personality does motivates followers (Nagendra and Farooqui, 2016; Grabo, et al., 2017). The second common trend among past literature reviews is decision making is shared by subordinates with the presence of an explanatory metanarrative under democratic leadership (Nagendra and Farooqui, 2016; Hudon and Rouillard, 2015). The third common trend among past literature reviews is managers motivates subordinates to do more than expected which may be immoral and unethical as caused by transformational leadership (Mutahar, et al, 2015; Vecchio, et al., 2008). The fourth common trend among past literature reviews is that employees place their trusts on the excellence and leadership skills of their transactional leaders (Obiwuru, et al., 2014; Yishuang, 2016).

The irregularity among past literature reviews is increased in employee turnover rate if the transactional leadership in SMEs in East Malaysia are not able to motivate employees to remain enthusiastic in their job position, the employees would want to join other organizations that practice charismatic leadership, hence transactional leadership would not increase organizational performance (Nagendra and Farooqui, 2016; Obiwuru, et al., 2014). The second irregularity among past literature reviews is that decision making that is centralized whereby decision-making is executed from one leader can be as important in increasing organizational performance as decision making that is decentralized whereby decision-making is shared by subordinates (Nagendra and Farooqui, 2016; Hudon and Rouillard, 2015). The third irregularity among past literature reviews is transformational leadership did not activate all employees' higher order needs, as only some employees in SMEs in East Malaysia find themselves being interested with their jobs, hence the remaining employees in 
SMEs in East Malaysia who did not feel intellectual stimulation from their transformational leaders would not trust and admire their transformational leaders (Obiwuru, et al., 2014; Vecchio, et al., 2008). The fourth irregularity among past literature reviews is feedbacks from some employees in SMEs in East Malaysia have shown that their transactional leaders would strictly require them to comply to standards but did not properly clarify goals to employees, which led to employees having to be punished for not complying to standards (Yishuang, 2016; Obiwuru, et al., 2014).

Most of the theories have supported the relationship between leadership style and organizational performance. For example, Great Man Theory supported the significant relationship between charismatic leadership, democratic leadership, transformational leadership, transactional leadership and organizational performance of SMEs in East Malaysia by indicating that the leader has a major role to play in the SME in East Malaysia. Therefore, for effective performance organizations should select a leader who is all round and who shares values with the employees to ensure that the organization culture embraced fosters performance (Borgatta et al., 1954). Moreover, Trait Theory supported that the leaders' openness to experience determines their effectiveness. The level of openness to experience of a leader determines their tolerance to ambiguity, their receptiveness to complex situations, ability to think divergently and creativity. All these factors are of much important in effective leadership thus influence achievement of organizational goals (Colbert et al., 2012). Role Theory supported that leaders' roles determine their ability to improve organization performance (Drysdale et al., 2016). This is because when the role aligns with what they like to do, they easily motivate the followers towards a certain direction of achieving goals.

Signaling Theory also supported the existence of significant relationship between charismatic leadership and organizational performance, because charismatic leaders helped to create an excitement in people for their work leading to higher productivity levels (Nagendra \& Farooqui, 2016). Leaders in SMEs in East Malaysia should making working activities fun, so that employees are attracted to leader and being exited and willingly cooperate with leaders. Malaysia government should have a clear vision for corporations in East Malaysia. Other than that, Critical Theory supported the existence of significant relationship between democratic leadership and organizational performance, because it captures the aggregate values of the SME firm in East Malaysia from the historical perspectives that it holds, democratic leadership in turn leads to the election of leaders who are supported by a majority of stakeholders (Hudon \& Rouillard, 2015; Nagendra \& Farooqui, 2016). Leaders in SMEs in East Malaysia should allow subordinate and employees to make decisions. Malaysia government should ensure that employees in East Malaysia are developing skills and knowledge.

Path-Goal Theory also supported the existence of significant relationship between transformational leadership and organizational performance, because transformational leadership encourages the election of a leader who explains to followers what is expected of them (Obiwuru et al., 2014). Path-Goal Theory holds that a leader seeks to get the viewpoints of employees on how tasks ought to be performed can create intellectual stimulation that will develop employees' performance goal, which leads to organizational performance (Choudhary et al., 2013). Leaders in SMEs in East Malaysia should allow employees to approach task in different new ways according to their own interests. Malaysia government should ensure that employees East Malaysia receive constant intellectual stimulation from task outcomes. Lastly, Contingency Theory supported the existence of significant relationship between transactional leadership and organizational performance, because the SMEs in East Malaysia that operate as open systems would make decisions depending on the situations they are faced with (Vecchio et al., 2008). Transactional leadership promotes responses that can be implemented in order to solve a particular problem, whereby employees get rewarded when goals are achieved and get punished if they have failed to follow orders (Mtimkulu et al., 2014). Future research needs to incorporate the other elements such as industry as a moderating variable in the framework. Leaders in SMEs in East Malaysia should ensure employees are developing corrective and constructive behaviours. Besides that, Malaysia government should set learning goals and standards for corporations in East Malaysia comply and follow.

\section{Acknowledgements}

I would like to thank the editors and the anonymous referees of the journal for constructive comments and suggestions, which have significantly helped to improve the contents of the paper. The usual caveats apply. I also would like to extend my sincere appreciation to Ministry of Higher Education (MOHE) for facilitating the project.

\section{References}

Akor, P. U. (2014). Influence of Autocratic Leadership Style on the Job Performance of Academic Librarians in Benue State. Journal of Educational and Social Research, 4(7), 148. 
https://doi.org/10.5901/jesr.2014.v4n7p148

Allen, G. P., Moore, W. M., Moser, L. R., Neill, K. K., Sambamoorthi, U., \& Bell, H. S. (2016). The Role of Servant Leadership and Transformational Leadership in Academic Pharmacy. American Journal of Pharmaceutical Education, 80(7), 113. https://doi.org/10.5688/ajpe807113

Al-Swidi, A. K., Nawawi, M. K. M., \& Al-Hosam, A. (2012). Is the relationship between employees' psychological empowerment and employees' job satisfaction contingent on the transformational leadership? A study on the Yemeni Islamic Banks. Asian Social Science, 8(10), 130. https://doi.org/10.5539/ass.v8n10p130

Arham, A. F., Boucher, C., \& Muenjohn, N. (2013). Leadership and entrepreneurial success: A study of SMEs in Malaysia. The World, 3(5), 117-130.

Ashford, S. J., Wellman, N., Sully De Luque, M., De Stobbeleir, K. E. M., \& Wollan, M. (2018). Two roads to effectiveness: CEO feedback seeking, vision articulation, and firm performance. Journal of Organizational Behavior, 39(1), 82-95. https://doi.org/10.1002/job.2211

Asiimwe, J. B., \& Sikalieh, D. (2012). The Relationship between Transactional Leadership Style and SMEs Growth in the Top 100 SMEs in Kenya.

Bakar, M. S., \& Mahmood, R. (2014). Linking transformational leadership and corporate entrepreneurship to performance in the public higher education institutions in Malaysia. Advances in Management and Applied Economics, 4(3), 109.

Beckford, J. (2016). Quality: A Critical Introduction. Taylor \& Francis. https://doi.org/10.4324/9781315644028

Borgatta, E., \& Bales, R. (2012). Some Findings Relevant To The Great Man Theory Of Leadership. Russell Sage Foundation and Harvard University.

Buoziute-Rafanaviciene, S., Pudziene, A., \& Turauskas, L. (2015). Relation between the attributes of executive successor and organizational performance. Engineering Economics, 62(2).

Cameron, K. S., \& Whetten, D. A. (Eds.). (2013). Organizational effectiveness: A comparison of multiple models. Academic Press.

Cavazotte, F., Moreno, V., \& Bernardo, J. (2013). Transformational leaders and work performance: the mediating roles of identification and self-efficacy. BAR-Brazilian Administration Review, 10(4), 490-512. https://doi.org/10.1590/S1807-76922013000400007

Chan, J. L., \& Quah, W. (2012). Start-up Factors for Small and Medium-sized Accommodation Businesses in Sabah, Malaysia: Push and Pull Factors. Asia Pacific Journal of Tourism Research, 17(1), 49-62. https://doi.org/10.1080/10941665.2011.610150

Choudhary, A. A., Akhtar, S., \& Zaheer, A. (2013). Effect of Transformational And Servant Leadership On Organizational Performance based on Comparative Analysis. Journal Of Business Ethics, 116(2), 433-440. https://doi.org/10.1007/s10551-012-1470-8

Clack, L. A. (2017). Examination of Leadership and Personality Traits on the Effectiveness of Professional Communication in Healthcare. Journal of Healthcare Communications. https://doi.org/10.4172/2472-1654.100051

Colbert, A. E., Judge, T. A., Choi, D., \& Wang, G. (2012). Assessing the trait theory of leadership using self and observer ratings of personality: The mediating role of contributions to group success. The Leadership Quarterly, 23, Leadership and Individual Differences, 670-685. https://doi.org/10.1016/j.leaqua.2012.03.004

Coleman, S., \& MacNicol, D. (2016). Project Leadership. Routledge. https://doi.org/10.4324/9781315270180

Conde, J. G., Sampedro, E. L. V., Feliu, V. R., \& Sánchez, M. B. G. (2013). Management control systems and ISO certification as resources to enhance internationalization and their effect on organizational performance. Agribusiness, 29(3), 392-405. https://doi.org/10.1002/agr.21300

Connelly, B. L., Certo, S. T., Ireland, R. D., \& Reutzel, C. R. (2017). Signaling Theory: A Review and Assessment. Journal of Management, 37(1), 39-67. https://doi.org/10.1177/0149206310388419

Daily Express. (2019a). Financial aid for Sabah SMEs. [online]. Retrieved May 1, 2019, from www.dailyexpress.com.my/news.cfm?NewsID $=129278$

Drysdale, L. (2016). Dare to Make a Difference: Successful Principals Who Explore the Potential of their Role. 
ISEA, 44(3).

Drysdale, L. D., Gurr, D. D., \& Goode, H. H. (2016). Dare to Make a Difference: Successful Principals Who Explore the Potential of their Role. International Studies In Educational Administration (Commonwealth Council For Educational Administration \& Management (CCEAM)), 44(3), 37-53.

Drysdale, L., Gurr, D., \& Goode, H. (2012). Dare to make a difference: Successful principals who explore the potential of their role.

Elder, L., \& Paul, R. (2010). Analytic Thinking (2nd ed.). [online] Retrieved July 24, 2017, from https://www.criticalthinking.org/ctmodel/logic-model1.htm

Faludi, A. (2013). A reader in planning theory (Vol. 5). Elsevier.

Fatihudin, D., \& Mochklas, M. (2018). How Measuring Financial Performance. International Journal of Civil Engineering and Technology, 9(6), 553-557.

Franke, G. R., Crown, D. F., \& Spake, D. F. (1997). Gender differences in ethical perceptions of business practices: a social role theory perspective. https://doi.org/10.1037/0021-9010.82.6.920

Grabo, A., Spisak, B. R., \& van Vugt, M. (2017). Charisma as signal: An evolutionary perspective on charismatic leadership. The Leadership Quarterly, 28(4), 473-485. https://doi.org/10.1016/j.leaqua.2017.05.001

Gündemir, S., Carton, A. M., \& Homan, A. C. (2019). The impact of organizational performance on the emergence of Asian American leaders. Journal of Applied Psychology, 104(1), 107. https://doi.org/10.1037/ap10000347

Hamerstone, J., \& Hough, M. (2013). A Woman's Framework for a Successful Career and Life. Springer. https://doi.org/10.1057/9781137314222

Hanggraeni, D., Ślusarczyk, B., Sulung, L. A. K., \& Subroto, A. (2019). The Impact of Internal, External and Enterprise Risk Management on the Performance of Micro, Small and Medium Enterprises. Sustainability, 11(7), 2172. https://doi.org/10.3390/su11072172

Harnich, S., \& Frank, C. (2012). Role Theory in International Relations. Taylor \& Francis.

Henry, C. (2013). New Paradigm of Systems Thinking. International Journal of Economics, Finance and Management, 2(5).

Horkheimer, M. (1937). Traditional and critical theory. Critical theory: Selected essays, 204.

House, R. J. (1974). Path-goal theory of leadership. Journal of Contemporary Business, 3, 1-97. https://doi.org/10.1348/096317907X202482

Hudon, P. A., \& Rouillard, C. (2015). Critical Management Studies and public administration: Reinterpreting democratic governance using critical theory and poststructuralism. Canadian Public Administration, 58(4), 527-548. https://doi.org/10.1111/capa.12132

Iqbal, N., Anwar, S., \& Haider, N. (2015). Effect of leadership style on employee performance. Arabian Journal of Business and Management Review, 5(5).

Islam, J., \& Hu, H. (2012). A review of literature on contingency theory in managerial accounting. African journal of business management, 6(15), 5159. https://doi.org/10.5897/AJBM11.2764

Jorge, D. M. A. M., \& E. Borges, R. S. G. (2017). Performance and Leadership Style: When Do Leaders and Followers Disagree? Revista de Administração Mackenzie, 18(2), 124-129. https://doi.org/10.1590/1678-69712016/administracao.v18n2p104-129

Kakucha, W. N. (2015). The Role of Charismatic Leadership in Change Management Using Kurt Lewin's Three Stage Model. The International Journal of Business \& Management, 3(10), 634.

Kele, A. T. B. A., Mohsin, A., \& Lengler, J. (2017). How willing/unwilling are luxury hotels' staff to be empowered? A case of East Malaysia. Tourism Management Perspectives, 22, 44-53. https://doi.org/10.1016/j.tmp.2017.01.006

Khan, N. R., Ghouri, A. M., \& Awang, M. (2013). Leadership styles and organizational citizenship behavior in small and medium scale firms. Journal of Arts, Science \& Commerce.

Koenig, A. M., \& Eagly, A. H. (2014). Evidence for the social role theory of stereotype content: Observations of groups' roles shape stereotypes. Journal of Personality and Social Psychology, 107(3), 371.

https://doi.org/10.1037/a0037215 
Kotane, I., \& Kuzmina-Merlino, I. (2017). Non-financial indicators for evaluation of business activity. European integration studies, 5, 213-219.

Lee, C. K. M., \& Lam, J. S. L. (2012). Managing reverse logistics to enhance sustainability of industrial marketing. Industrial Marketing Management, 41(4), 589-598. https://doi.org/10.1016/j.indmarman.2012.04.006

Li, Y., \& Tan, C. H. (2013). Matching business strategy and CIO characteristics: The impact on organizational performance. Journal of Business Research, 66(2), 248-259. https://doi.org/10.1016/j.jbusres.2012.07.017

Limpitikranon, W. (2017). The Effects of a High Performance Work System and Leader-Member Exchange on Organizational Performance in the Thai Hospitality Industry.

Linda, J. S., \& Nevile, A. S. (2016). Keeping it together: The role of transactional situation awareness in team performance. International journal of industrial ergonomics, 53, 267-273. https://doi.org/10.1016/j.ergon.2016.02.007

Linton, G. (2014). Contingency theory in entrepreneurship research. Örebro University School of Business.

Madani, S. (2019). Time for Sabah, Sarawak to play bigger role. [online]. Retrieved May 1, 2019, from https://www.theborneopost.com/2019/02/21/time-for-sabah-sarawak-to-play-bigger-role/

Magzan, M. (2012). Mental Models For Leadership Effectiveness: Building Future Different Than The Past. Journal Of Engineering Management And Competitiveness (Jemc), 2(2), 57-63. https://doi.org/10.5937/jemc1202057M

Malik, S. H. (2013). Relationship between Leader Behaviors and Employees' Job Satisfaction: A Path-Goal Approach. Pakistan Journal of Commerce \& Social Sciences, 7(1).

Manning, G. (2014). The Art of Leadership. McGraw-Hill Higher Education.

Marx, T. G. (2014). The leader as chief strategist. Journal of Leadership Education, 13(1), 75-93. https://doi.org/10.12806/V13/I1/T1

Masa'deh, R. E., Obeidat, B. Y., \& Tarhini, A. (2016). A Jordanian empirical study of the associations among transformational leadership, transactional leadership, knowledge sharing, job performance, and firm performance based on structural equation modelling approach. Journal of Management Development, 35(5), 681-705. https://doi.org/10.1108/JMD-09-2015-0134

Moghimi, S., \& Subramaniam, I. D. (2013). Employees' creative behavior: The role of organizational climate in Malaysian SMEs. International Journal of Business and Management, 8(5), 1-12. https://doi.org/10.5539/ijbm.v8n5p1

Mtimkulu, D. S., Naranjee, N., \&Karodia, A. M. (2014). An evaluation of the leadership styles of managers and their impact on human capital factors of motivation, performance and absenteeism of employees at selected hospitals in Eastern Free State, South Africa. Arabian Journal of Business and Management Review (Nigerian Chapter), 2(10), 10-41. https://doi.org/10.12816/0011632

Mustafa Kamal, E., \& Flanagan, R. (2012). Understanding absorptive capacity in Malaysian small and medium sized (SME) construction companies. Journal of Engineering, Design and Technology, 10(2), 180-198. https://doi.org/10.1108/17260531211241176

Mutahar, A. Y., Rasli, A. M., \& Al-Ghazali, B. M. (2015). Relationship of Transformational Leadership, Organizational Learning and Organizational Performance. International Journal of Economics and Financial Issues, 5(1S).

Nagendra, A., \& Farooqui, S. (2016). Role Of Leadership Style On Organizational Performance. Clear International Journal Of Research In Commerce \& Management, 7(4), 65-67.

Neil, C. (2019). SMEs assured of help, says CM. [online]. Retrieved May 1, 2019, from www.dailyexpress.com.my/news/133061/smes-assured-of-help-says-cm/

Nelson, D., \& Quick, J. (2013). Organizational Behavior: Science, The Real World, and You. Cengage Learning.

Newark, D. (2018). Leadership and the Logic of Absurdity. Academy of Management Review, 43(2), 198-216. https://doi.org/10.5465/amr.2015.0186

Nikoloski, K. (2015). Charismatic leadership and power: using the power of charisma for better leadership in the enterprises. Journal of Process Management-New Technologies, International, 3(2), 18-27. 
Northouse, P. G. (2015). Leadership: Theory and practice. Sage publications.

Noruzy, A., Dalfard, V. M., Azhdari, B., Nazari-Shirkouhi, S., \& Rezazadeh, A. (2013). Relations between transformational leadership, organizational learning, knowledge management, organizational innovation, and organizational performance: an empirical investigation of manufacturing firms. The International Journal of Advanced Manufacturing Technology, 64(5-8), 1073-1085.

https://doi.org/10.1007/s00170-012-4038-y

Obiwuru Timothy, C., Andy T., Akpa, V., \& Nwankwere Idowu, A. (2014). Effects Of Leadership Style On Organizational Performance: A Survey Of Selected Small Scale Enterprises In Ikosi-Ketu Council Development Area Of Lagos State, Nigeria.

Paraschiv, D. (2013). A review of leadership. Versita, 21(2), 253-262. https://doi.org/10.2478/auom-2013-0037

Polston-Murdoch, L. (2013). An Investigation of path-goal theory, relationship of leadership style, supervisor-related commitment, and gender. Emerging Leadership Journeys, 6(1), 13-44.

Rimbunan Sawit Berhad. (2019). glassdoor. [online]. Retrieved May 1, 2019 from https://www.glassdoor.com/Reviews/Rimbunan-Sawit-Berhad-Reviews E567584.htm

Royce, T. (2019). SMEs still not ready for fourth industrial revolution. [online]. Retrieved May 1, 2019 from https://www.thestar.com.my/business/business-news/2019/04/05/smes-still-not-ready-for-fourth-industrial revolution/\#k0e1YH2mwpP4DDyC.99.https://www.thestar.com.my/business/business-news/2019/04/05/sm es-still-not-ready-for-fourth-industrial-revolution/

Ryckman, R. M. (2012). Theories of personality. UK: Cengage Learning.

Sajjadi, A. (2014). New emerging leadership theories and styles. Technical Journal of Engineering and Applied Sciences, 4(3), 180-188.

Sarawak Energy Berhad. glassdoor. [online]. Retrieved May 1, 2019 from https://www.glassdoor.com/Reviews/Sarawak-Energy-Berhad-Reviews-E574319.htm

Scouller, J. (2016). The Three Levels of Leadership 2nd Edition: How to Develop Your Leadership Presence, Knowhow and Skill. Management Books 2000 Limited.

SEGi University. glassdoor. [online]. Retrieved $\quad$ May $1, \quad 2019$ from https://www.glassdoor.com/Reviews/SEGi-University-Reviews-E508752.htm

Sherell, J. (2019). 'Tonnes of money but nothing to spend on'. [online]. Retrieved May 1, 2019 from <www.dailyexpress.com.my/news/133293/tonnes-of-money-but-nothing-to-spend-on-/

Silva, A. (2015). An Integrated Leadership Theory. Journal of Perspectives in Organizational Behavior, Management, \& Leadership, 1(1), 5-9.

Smither, R., Houston, J., \& McIntire, S. (2016). Organization development: Strategies for changing environments. Routledge. https://doi.org/10.4324/9781315732046

SOPB. (2019). glassdoor. [online]. Retrieved May 1, 2019 from https://www.glassdoor.com/Reviews/SOPB-Reviews-E406111.htm

Srivastava, P. C. (2016). Leadership Styles in Western \& Eastern Societies and Its Relation with Organizational Performance. Pranjana: The Journal of Management Awareness, 19(1), 60-76. https://doi.org/10.5958/0974-0945.2016.00006.6

Stutje, J. (2012). Charismatic Leadership and Social Movements: The Revolutionary Power of Ordinary Men and Women. Berghahn Books.

Su, W., \& Cheung, Y. L. (2016). The signaling effect of corporate social responsibility in emerging economies. Journal of business Ethics, 134(3), 479-491. https://doi.org/10.1007/s10551-014-2404-4

Sultana, U., \& Darun, M. R. (2015). Transactional Or Transformational Leadership: Which Works Best For Now? International Journal of Industrial Management.

Ufen, A. (2015). Laissez-faire versus Strict Control of Political Finance: Hegemonic Parties and Developmental States in Malaysia and Singapore. Critical Asian Studies, 47(4), 564-586. https://doi.org/10.1080/14672715.2015.1082263

Valmohammadi, C., \& Ahmadi, M. (2015). The effect of knowledge management practices on organizational performance based on balanced scorecard approach. Journal of Enterprise Information Management, 28(1), 


\section{1-159. https://doi.org/10.1108/JEIM-09-2013-0066}

Vecchio, R. P., Justin, J. E., \& Pearce, C. L. (2008). The utility of transactional and transformational leadership for predicting performance and satisfaction within a path-goal theory framework. Journal Of Occupational \& Organizational Psychology, 81(1).

WeMotor. (2017). Dmw 1 Automobile Sdn Bhd. We Motor. [Online] Retrieved June 25, 2017, from https://www.wemotor.com/car-dealers/1390/

WeMotor.com. (2017). DMW 1 Automobile Service. We Motor. [Online] Retrieved June 25, 2017, from https://www.wemotor.com/car-dealers/1390/

Westaby, J. D., \& Lee, B. C. (2010). Leadership decision-making: A behavioral reasoning theory analysis. The Leadership Quarterly, 21(3), 481-495. https://doi.org/10.1016/j.leaqua.2010.03.011

Wickramasinghe, D., \& Alawattage, C. (2012). Management Accounting Change: Approaches and Perspectives. Routledge.

Woodward, J. (1958). The Michigan Alumnus .UM Libraries.

X-FAB Sarawak. (2019). glassdoor. [online]. Retrieved May 1, 2019, from https://www.glassdoor.com/Reviews/X-FAB-Sarawak-Reviews-E15785.htm

Yagambaram, L. (2012). Effects of leadership style on job satisfaction in small and medium enterprises (SMEs) in Malaysia (Doctoral dissertation, USM).

Yahaya, A., Osman, I., \& Issah, E. (2014). Assessing the effects of leadership styles on staff productivity in tamale polytechnic, Ghana. International Journal of Economics, Commerce and Management, 2(9).

Yishuang, M. (2016). Spiritual leadership at the workplace: Perspectives and theories (Review). Biomedical Reports, 5(4), 408-412. https://doi.org/10.3892/br.2016.748

Yusuf, M. O., \& Kazeem, A. O. (2014). Management of leadership style: an approach to organizational performance and effectiveness in Nigeria. International Journal of Humanities Social Sciences and Education, 1(2), 17-29.

\section{Copyrights}

Copyright for this article is retained by the author(s), with first publication rights granted to the journal.

This is an open-access article distributed under the terms and conditions of the Creative Commons Attribution license (http://creativecommons.org/licenses/by/4.0/). 